\title{
PESTICIDES IN STREAMS IN NEW JERSEY AND LONG ISLAND, NEW YORK, AND RELATION TO LAND USE
}

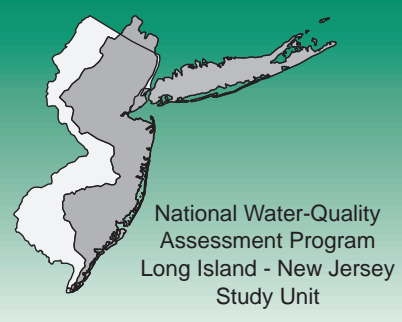

\section{Abstract}

Pesticide compounds were detected in all 50 water samples collected from streams in New Jersey and Long Island, New York, during June 9-18, 1997. Samples were analyzed for 47 compounds, of which 25 were detected. The number of pesticides detected at each site ranged from 1 to 14 . The seven most frequently detected pesticides were atrazine (in 93 percent of samples), metolachlor (86 percent), prometon ( 84 percent), desethyl-atrazine ( 78 percent), simazine ( 78 percent), carbaryl (44 percent), and diazinon (44 percent).

All pesticide concentrations were within both U.S. Environmental Protection Agency (USEPA) and State maximum contaminant levels (MCL's) for drinking water and USEPA lifetime health advisory levels (HAL's). Concentrations of dieldrin and methylazinphos at one or more sites, however, equaled or exceeded a Federal or State water-quality criterion for aquatic life.

The pesticides detected in a stream were related to the land-use composition of the basin. Detection frequencies of 14 of the 25 pesticides detected were highest at agricultural sites; acetochlor, azinphos-methyl, carbofuran, and pebulate were detected only at agricultural sites. Seven compounds were detected most frequently at urban sites; trifluralin, dieldrin, napropamide, and benfluralin were detected only at urban sites. Four compounds were detected most frequently at sites draining areas of mixed land use. No pesticides were detected most frequently at sites draining forested areas.

The median concentration and the detection frequency of a given pesticide always were highest in samples from sites in the same land-use category.The median concentrations of seven pesticides at the agricultural sites were at least twice as high as the median concentrations at sites in other land-use categories. The median concentrations of the seven compounds detected most frequently at urban sites were equal to or only slightly higher than the median concentrations at sites in other land-use categories.

The median total-pesticide concentration was highest at agricultural sites $(0.2 \mu \mathrm{g} / \mathrm{L}$ (micrograms per liter)) and lowest at forested sites $(0.025 \mu \mathrm{g} / \mathrm{L})$. Total-pesticide concentrations varied most at agricultural sites and least at forested sites. Total-pesticide concentration and number of pesticides detected at a site increased as the percentage of agricultural land in the basin increased and decreased as the percentage of undeveloped land increased.

Only three of the seven most frequently detected compounds-atrazine, metolachlor, and carbaryl—are among the seven most heavily applied pesticides in New Jersey. This is because detection frequencies are the result of physical and chemical properties of the pesticide compounds as well as application rates. Water solubility and soil-adsorption coefficients appear to be the two physical properties of pesticides that most influence their presence in streams.

\section{Introduction}

Pesticides are synthetic organic compounds widely used in the United States to control insects (insecticides), unwanted vegetation (herbicides), and fungi (fungicides). Approximately 1.1 billion pounds of pesticides are used annually in the United States (Ware, 1994). Pesticides are used primarily for agriculture, lawn care, golf-course maintenance, termite control, and right-of-way maintenance. The use of herbicides quadrupled from 1966 to 1991 (Larson and others, 1997). In 1991, 76 percent of the pesticides sold in the United States were used for agricultural purposes; industry and government used 18 percent, and home and garden use represented 6 percent of total sales (Ware, 1994).

Pesticide use has significantly increased agricultural productivity; however, potential adverse effects on nontarget organisms and the environment in general have become a matter of concern. For example, organochlorine insecticides such as DDT and dieldrin were banned from use in the United States in
1973 and 1984, respectively, because of bioaccumulation in the food chain and related adverse health effects on nontarget organisms (Harte and others, 1991). Organochlorine insecticides have been replaced by less persistent and more water-soluble organophosphate and carbamate compounds, reducing the risk of accumulation in sediments and the food chain, but increasing the risk of widespread low levels of dissolved pesticides entering surface-water and ground-water systems.

The U.S. Geological Survey (USGS) National Water Quality Assessment (NAWQA) program is designed to assess the status of the Nation's water quality, describe trends in water quality, and provide a sound scientific understanding of the primary natural and human factors that affect the quality of the Nation's water resources. One component of the NAWQA program is the study of pesticides to determine their occurrence, concentrations, and seasonal variability in surface and ground water throughout the country.

The study described here was conducted as part of the Long Island-New Jersey (LINJ) coastal drainages NAWQA 


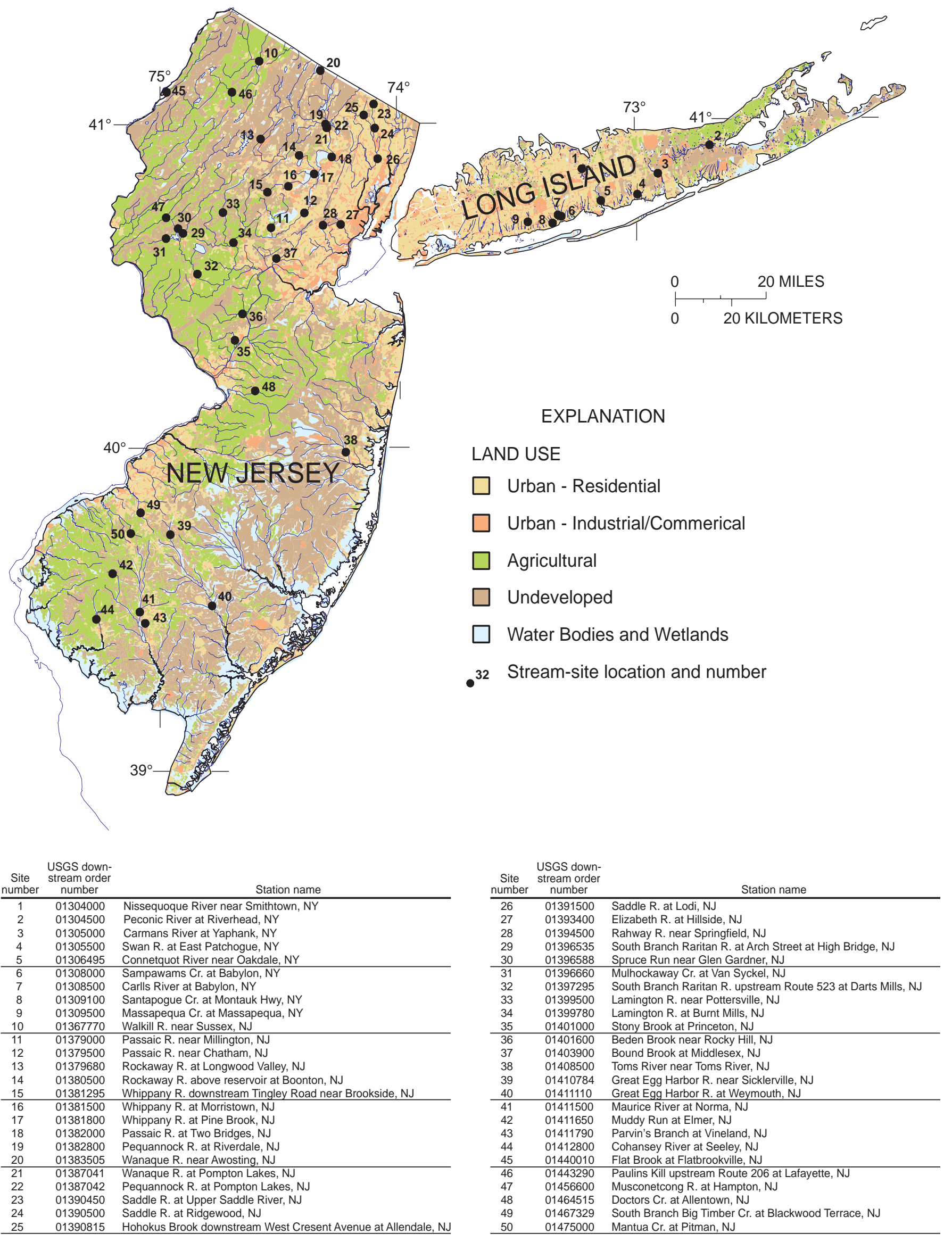

Figure 1. Locations of 50 stream sites in New Jersey and Long Island, New York, sampled for pesticides, June 9-18, 1997. 
project. The LINJ study area is one of 59 areas studied nationwide. The population of the study area, which includes northeastern New Jersey and western Long Island, two of the most densely populated areas in the United States, exceeds 10 million (U.S. Bureau of the Census, 1991). In 1990, 44 percent of the study area was used for residential, commercial, and industrial purposes, 30 percent was forested, 12 percent was used for agriculture, 8 percent was wetlands, and 6 percent was classified as miscellaneous (percentages modified from Fegeas and others, 1983, by using the method described in Hitt, 1994).

Two previous investigations of pesticides in surface water in the study area focused on relatively small areas. Results of a study of pesticides in agricultural runoff from six New Jersey drainage basins showed that 10 of the 21 pesticides measured were detected at low concentrations (Ivahnenko and Buxton, 1993). In the 28 samples collected, the concentration of only one pesticide in one sample exceeded the U.S. Environmental Protection Agency (USEPA) lifetime health advisory level (HAL). A second study assessed the vulnerability of publicwater supplies to pesticide contamination in the Millstone and Shark River Basins (Buxton and Dunne, 1993). In the Millstone River, only 4 of 20 pesticides were detected, at low concentrations, during base flow and stormflow. No pesticides were detected in base-flow or stormflow samples from the Shark River. A larger scale retrospective study summarized pesticide data from 463 surface-water sites in the eight-state Mid-Atlantic region from southern New York to northern North Carolina. At least one compound was detected at more than 90 percent of the sites and 16 compounds were frequently detected, 3 in concentrations greater than the USEPA maximum contaminant level (MCL) (Ferrari and others, 1997). Detection frequencies are inversely related to the detection limits of the analytical methods used in each study. The minimum reporting level (MRL) at the laboratory during the previous studies in New Jersey was 0.03 $\mu \mathrm{g} / \mathrm{L}$ (micrograms per liter); those used in this study ranged from 0.001 to $0.018 \mu \mathrm{g} / \mathrm{L}$.

This report documents the presence and spatial variability of pesticides in streams throughout New Jersey and Long Island, New York. It presents the results of analyses of 50 water samples collected during June 9-18, 1997 (fig. 1), from streams that drain basins in a variety of physiographic and land-use settings. Detection frequencies and concentrations of pesticides are examined with respect to land uses in the drainage basins studied.

\section{Selection of Sampling Sites}

Fifty-three stream sites were chosen to represent the variety of land uses, physiographic settings, and other drainagebasin characteristics in the study area (fig. 1). Samples were collected at the LINJ NAWQA network of 7 sites sampled on a routine basis and at 31 sites sampled for LINJ NAWQA ecological studies. The additional 15 sites were chosen to represent streams in other areas of the Coastal Plain of New Jersey and Long Island and to include multiple sites along stream reaches where land use and point-source influences change downstream.

Land use, drainage area, and physiographic province were considered in site selection. Sites were chosen to represent the range in amounts of urban land use in the study area. The percentage of urban land use (residential, commercial, and industrial) associated with the sampling sites ranges from 2 to 93 percent. Agricultural and forested land uses range from 0 to 77 percent and 3 to 89 percent, respectively. For comparative purposes, sites were grouped into one of four land-use categories on the basis of the percentage of each land use in the associated basin: urban ( $>50$ percent), agricultural $(>25$ percent), forest ( $>50$ percent), and mixed land use. The number of sites in each of these categories was $18,13,14$, and 8 , respectively; however, the agricultural category was reduced to 10 sites because 3 of the 13 samples could not be analyzed. Total undeveloped land (forested, barren, wetlands, and water bodies) was compared to total developed land (urban and agricultural) in each basin. Land-use data from 1986 were used for this study (N.J. Department of Environmental Protection, 1996). Drainage areas of the stream sites selected (from 5 to 804 square miles) encompass the range of basin sizes found in the study area. Nineteen sites are in the Coastal Plain, 24 are in the Piedmont, and 7 are in the New England and Valley and Ridge physiographic provinces.

\section{Field and Laboratory Methods}

Surface water was sampled at 53 sites in New Jersey and on Long Island during June 9-18, 1997. Samples were collected in late spring, soon after the heaviest application of pesticides, when pesticide concentrations were expected to be highest and streamflow was at or near base-flow conditions. Stream samples were collected using NAWQA protocols (Shelton, 1994). The samples were collected in Teflon bottles and split for multiple analyses. Samples were filtered in the field at each site to remove suspended particulate matter and shipped on ice to the USGS National Water Quality Laboratory (NWQL). Samples from three sites were accidentally destroyed at the lab, reducing the number of samples analyzed to 50. All samples were analyzed for 47 pesticides ( 25 herbicides, 20 insecticides, and 2 degradation products) as well as nutrients, major ions, suspended sediment, dissolved organic carbon, and suspended organic carbon. The results of these analyses are available in Reed and others (1998).

The NWQL uses a gas-chromatography/mass spectrometry (GC/MS) technique (Zaugg and others, 1995) that allows for the accurate detection and quantification of pesticide compounds at concentrations ranging from 0.001 to $0.018 \mu \mathrm{g} / \mathrm{L}$. Results are censored when concentrations cannot be accurately determined as a result of analytical and (or) other limitations. Values are reported as less than the MRL when a pesticide is not present at a concentration that can be identified and measured by using NWQL analytical procedures. Estimated values (indicated with an "E" prefix) are reported when the presence of a compound is certain but confidence in accurate quantification is small. Concentrations of four compounds-azinphos-methyl, carbaryl, carbofuran, and desethyl-atrazine_-are always reported with an "E" code because of variable quantification performance of GC/MS (Zaugg and others, 1995). Forty-eight percent of the 356 pesticide concentrations reported in this study were estimated values.

Quality-control samples were collected and analyzed to ensure the quality of the data. Three field-equipment blanks were analyzed to determine the possibility of contamination during 
Table 1. Pesticide use reported by licensed applicators in the study area, in pounds of active ingredient, for pesticides detected in samples from 50 stream sites in New Jersey and Long Island, New York

[Red, seven most frequently detected compounds; DP, degradation product; N/A, not available; NF, Not used after 1984; NP, Not used prior to 1994; NCFAP, National Center for Food and Agricultural Policy; NJPCP, unpublished data on file at N.J. Department of Environmental Protection, Pesticide Control Program, Trenton, N.J., 1992, 1993, 1994, 1995]

\begin{tabular}{|c|c|c|c|c|c|c|c|c|}
\hline \multirow{2}{*}{ Pesticide } & $\begin{array}{c}\text { New Jersey / } \\
\text { Long Island } \\
\text { study area } \\
\text { (NCFAP) }\end{array}$ & \multicolumn{7}{|c|}{$\begin{array}{c}\text { New Jersey (NJPCP) } \\
7,468 \text { square miles }\end{array}$} \\
\hline & Agriculture & $\begin{array}{l}\text { Agriculture } \\
\text { (1994) }\end{array}$ & $\begin{array}{l}\text { Lawn care } \\
\text { (1995) }\end{array}$ & $\begin{array}{c}\text { Golf courses } \\
\text { (1993) }\end{array}$ & $\begin{array}{l}\text { Rights-of-way } \\
\text { (1993) }\end{array}$ & $\begin{array}{c}\text { Mosquito } \\
\text { control (1993) }\end{array}$ & $\begin{array}{c}\text { Termite } \\
\text { control (1992) }\end{array}$ & Total \\
\hline \multicolumn{9}{|c|}{ Herbicides } \\
\hline Metolachlor & 96,001 & 137,387 & 132 & 2 & 0 & 0 & 0 & 137,521 \\
\hline Pendimethalin & 7,327 & 20,027 & 49,141 & 2,587 & 34 & 0 & 0 & 71,755 \\
\hline Atrazine & 47,856 & 58,790 & 18 & 0 & 3 & 0 & 0 & 58,81 \\
\hline Alachlor & 23,130 & 48,945 & 0 & 0 & 0 & 0 & 0 & 48,945 \\
\hline DCPA & 8,690 & 24,376 & 1,570 & 7,626 & 0 & 0 & 0 & 33,572 \\
\hline Linuron & 12,748 & 24,132 & 0 & 0 & 0 & 0 & 0 & 24,132 \\
\hline Benfluralin & 1,061 & 257 & 19,612 & 1,647 & 0 & 0 & 0 & 21,516 \\
\hline Cyanazine & 10,076 & 18,233 & 18 & 0 & 0 & 0 & 0 & 18,251 \\
\hline Trifluralin & 5,118 & 5,055 & 9,957 & 279 & 0 & 0 & 0 & 15,291 \\
\hline Napropamide & 6,208 & 9,233 & 296 & 0 & 0 & 0 & 0 & 9,529 \\
\hline Metribuzin & 2,821 & 9,182 & 0 & 0 & 0 & 0 & 0 & 9,182 \\
\hline Simazine & 7,362 & 5,846 & 51 & 0 & 1,833 & 0 & 0 & 7,730 \\
\hline Terbacil & 4,000 & 2,318 & 0 & 0 & 0 & 0 & 0 & 2,318 \\
\hline Prometon & N/A & 85 & 866 & 0 & 246 & 0 & 0 & 1,197 \\
\hline Pebulate & N/A & 334 & 0 & 0 & 0 & 0 & 0 & 334 \\
\hline Tebuthiuron & N/A & 1 & 4 & 0 & 119 & 0 & 0 & 124 \\
\hline Acetochlor & NP & 2,723 & 0 & $\mathrm{NP}$ & NP & $\mathrm{NP}$ & NP & N/A \\
\hline Atrazine, desethyl & $\mathrm{DP}$ & DP & $\mathrm{DP}$ & DP & DP & DP & DP & N/A \\
\hline \multicolumn{9}{|c|}{ Insecticides } \\
\hline Chlorpyrifos & 10,881 & 15,230 & 28,107 & 8,662 & 0 & 19 & 84,729 & 136,747 \\
\hline Carbaryl & 10,713 & 16,331 & 9,563 & 2,650 & 0 & 0 & 0 & 28,544 \\
\hline Azinphos, methyl & 8,147 & 22,609 & 0 & 0 & 0 & 0 & 0 & 22,609 \\
\hline Malathion & 298 & 3,923 & 343 & 0 & 0 & 11,506 & 0 & 15,772 \\
\hline Diazinon & 7,029 & 12,641 & 1,032 & 0 & 0 & 0 & 0 & 13,673 \\
\hline Carbofuran & 5,338 & 10,353 & 0 & 0 & 0 & 0 & 0 & 10,353 \\
\hline Dieldrin & $\mathrm{NF}$ & NF & $\mathrm{NF}$ & $\mathrm{NF}$ & $\mathrm{NF}$ & $\mathrm{NF}$ & $\mathrm{NF}$ & $\mathrm{NF}$ \\
\hline
\end{tabular}

collection and processing of the samples. Four sets of split replicate samples were used to evaluate the variability in the analytical techniques, and two sample matrix spikes were used to evaluate potential bias and the ability of the analytical technique to recover analytes from the water-sample matrix. One of the spiked samples was not analyzed.

\section{Pesticide Use in the Study Area}

Data on the application of pesticides for agricultural purposes in the study area (in pounds of active ingredient) has been compiled in two data bases. The National Center for Food and Agricultural Policy (NCFAP) data base was developed from estimates of pesticide applications on cropland in 1992. Pesticide-application data for cropland in the LINJ coastal drainages study area were extracted from this data base and are listed in table 1. The New Jersey Pesticide Control Program (NJPCP) data base, developed from a 1994 survey of licensed applicators, was compiled for the State of New Jersey only, and includes applications reported by ranchers, sod farmers, Christmas tree growers, and nursery and greenhouse operators in addition to farmers growing field crops. As a result, the amounts applied for agriculture in the NJPCP data base are higher than those in the NCFAP data base for most compounds. The NJPCP data base also contains results of surveys of licensed applicators for information regarding use of pesticides for lawn care, golfcourse and right-of-way maintenance, and mosquito and termite control.
Pesticide use is summarized in the NJPCP data base for all compounds analyzed for in this study, although only those pesticides detected are included in table 1. Herbicides most commonly used in New Jersey are metolachlor, atrazine, and alachlor for agriculture; pendimethalin, benfluralin, and trifluralin for professional lawn care; dacthal, pendimethalin, and benfluralin for golf courses; and simazine, triclopyr, and prometon for weed control along transportation and utility rights-of-way. The most commonly used insecticides are methylazinphos, carbaryl, and chlorpyrifos for agriculture; chlorpyrifos, carbaryl, and fonofos for professional lawn care; chlorpyrifos, carbaryl, and ethoprop on golf courses; chlorpyrifos and permethrin for termite control; and malathion and permethrin for mosquito control. Alachlor, linuron, metribuzin, terbacil, pebulate, acetochlor, methyl-azinphos, and carbofuran are used only in agriculture. At least 97 percent of the metolachlor, atrazine, cyanazine, and napropamide used is applied to agricultural land (table 1). Simazine can be applied directly to water for the control of algae (Larson and others, 1997), but none has been registered for this use in New Jersey since 1994.

\section{Presence of Pesticides and Relation to Land Use}

A total of 25 pesticides were detected in the streamwater samples from the 50 sites. At least one pesticide was detected at each site. Detection frequency and median and maximum concentrations of detected compounds are listed in table 2, along 
Table 2. Pesticides detected in 50 stream samples collected in New Jersey and Long Island, New York, June 9-18, 1997

[NWQL, U.S. Geological Survey National Water Quality Laboratory; MRL, minimum reporting level; EPA MCL, maximum contaminant level (U.S Environmental Protection Agency, 1996); EPA HAL, health-advisory level, 70-kilogram adult, lifetime (U.S. Environmental Protection Agency, 1996); NJ MCL, New Jersey maximum contaminant level (New Jersey Department of Environmental Protection, 1998); NJ HHC, New Jersey human health criteria, (New Jersey Department of Environmental Protection, 1998); NY MCL, New York maximum contaminant level (New York State, 1998). Water-quality criteria for aquatic life are as follows: EPA, U. S. freshwater chronic criteria for aquatic life (U.S. Environmental Protection Agency, 1995); CAN, Canadian water-quality guidelines (Canadian Council of Resource and Environment Ministers, 1996); GL, Great Lakes water quality objectives (International Joint Commission Canada and United States, 1977); NJ, New Jersey freshwater water quality criteria (New Jersey Department of Environmental Protection, 1998); NY, New York State water quality criteria (New York State, 1998); $\mu$ g/L, micrograms per liter; --, criteria do not exist; E, estimated value; Red, one of the seven most frequently detected compounds]

\begin{tabular}{|c|c|c|c|c|c|c|c|c|c|c|}
\hline $\begin{array}{l}\text { Compound name } \\
\text { (NWQL) }\end{array}$ & Trade name & $\begin{array}{l}\text { MRL } \\
(\mu \mathrm{g} / \mathrm{L})\end{array}$ & Rank & $\begin{array}{l}\text { Detection } \\
\text { frequency, } \\
\text { in percent } \\
\text { (number of } \\
\text { detections) }\end{array}$ & $\begin{array}{c}\text { Median } \\
\text { concentration } \\
\text { of detections } \\
(\mu \mathrm{g} / \mathrm{L})\end{array}$ & $\begin{array}{c}\text { Maximum } \\
\text { concentration } \\
\text { of detections } \\
(\mu \mathrm{g} / \mathrm{L})\end{array}$ & $\begin{array}{c}\text { Site of } \\
\text { maximum } \\
\text { concentration } \\
\text { (fig. 1) }\end{array}$ & $\begin{array}{c}\text { MCL,HAL } \\
\text { or HHC } \\
(\mu \mathrm{g} / \mathrm{L})\end{array}$ & $\begin{array}{c}\text { Water-quality } \\
\text { criteria for } \\
\text { aquatic life } \\
(\mu \mathrm{g} / \mathrm{L})\end{array}$ & $\begin{array}{c}\text { Percent } \\
\text { exceedence } \\
\text { (number of } \\
\text { samples) }\end{array}$ \\
\hline Acetochlor & Harness Plus, Surpass & 0.002 & 17 & $6(3)$ & 0.15 & 0.25 & 01401600 & - & -- & -- \\
\hline Alachlor & Lasso, Bullet, Bronco & 0.002 & 9 & $30(15)$ & 0.004 & 0.09 & 01464515 & 2 EPA MCL & $0.5 \mathrm{NY}$ & 0 \\
\hline Atrazine & $\begin{array}{l}\text { AAtrex, Atred, } \\
\text { Gesaprim }\end{array}$ & 0.001 & 1 & $94(47)$ & 0.008 & 1.44 & 01401000 & 3 EPA MCL & $2 \mathrm{CAN}$ & 0 \\
\hline Arazine, desethyl- & & 0.002 & 4 & $78(39)$ & E0.003 & E0.07 & 01401000 & - & -- & -- \\
\hline Azinphos, methyl & Guthion, Gusathion & 0.001 & 21 & $2(1)$ & E0.01 & E0.01 & 01475000 & 50 NY MCL & $\begin{array}{l}0.01 \mathrm{EPA} \\
0.005 \mathrm{NY}\end{array}$ & $2(1)$ \\
\hline Benfluralin & $\begin{array}{l}\text { Benefin, Balan, } \\
\text { Bonalan } \\
\end{array}$ & 0.002 & 21 & $2(1)$ & E0.002 & E0.002 & 01394500 & 50 NY MCL & -- & -- \\
\hline Carbaryl & $\begin{array}{c}\text { Sevin, Carbamine, } \\
\text { Denapon }\end{array}$ & 0.003 & 6 & $44(22)$ & E0.03 & E0.19 & 01381800 & $\begin{array}{c}700 \text { EPA HAL } \\
50 \text { NY MCL }\end{array}$ & -- & 0 \\
\hline Carbofuran & Furandan, Curaterr & 0.003 & 15 & $10(5)$ & E0.007 & E0.132 & 01464515 & 40 EPA MCL & $1.75 \mathrm{CAN}$ & 0 \\
\hline Chlorpyrifos & $\begin{array}{l}\text { Brodan, Dursban, } \\
\text { Lorsban } \\
\end{array}$ & 0.004 & 10 & $26(13)$ & 0.005 & 0.022 & 01403900 & $\begin{array}{l}20 \text { EPA HAL } \\
50 \text { NY MCL }\end{array}$ & $0.041 \mathrm{EPA}$ & 0 \\
\hline Cyanazine & Bladex, Fortrol & 0.004 & 1 & $18(9)$ & 0.006 & 0.622 & 01464515 & $\begin{array}{c}1 \text { EPA HAL } \\
50 \text { NY MCL }\end{array}$ & $2 \mathrm{CAN}$ & 0 \\
\hline DCPA & $\begin{array}{l}\text { Dacthal, Chlorthal- } \\
\text { dimethyl }\end{array}$ & 0.002 & 8 & $36(18)$ & E0.0015 & 0.287 & 01411790 & 50 NY MCL & -- & -- \\
\hline Diazinon & $\begin{array}{c}\text { Basadin, Diazatol, } \\
\text { Knox Out }\end{array}$ & 0.002 & 6 & $44(22)$ & 0.006 & 0.074 & 01391500 & \begin{tabular}{|c|}
$0.6 \mathrm{EPA} H A L$ \\
$50 \mathrm{NY}$ MCL
\end{tabular} & $0.08 \mathrm{GL}$ & 0 \\
\hline Dieldrin & $\begin{array}{c}\text { Panoram D-31, Octa- } \\
\text { lox }\end{array}$ & 0.001 & 17 & $6(3)$ & 0.014 & 0.019 & 01309500 & $\begin{array}{r}5 \mathrm{NY} \mathrm{MCL} \\
0.000135 \mathrm{NJ} \\
\mathrm{HHC}\end{array}$ & $\begin{array}{r}0.0625 \mathrm{EPA} \\
0.0019 \mathrm{NJ} \\
0.000007 \mathrm{NY}\end{array}$ & $6(3)$ \\
\hline Linuron & Lorex, Linex, Sarclex & 0.002 & 19 & $4(2)$ & 0.044 & 0.048 & 01464515 & $50 \mathrm{NY}$ MCL & 7 CAN & 0 \\
\hline Malathion & Cythion & 0.005 & 14 & $12(6)$ & 0.007 & 0.012 & 01308000 & $\begin{array}{c}200 \text { EPA HAL } \\
50 \text { NY MCL } \\
\end{array}$ & $0.1 \mathrm{EPA}$ & 0 \\
\hline Metolachlor & Dual, Pennant & 0.002 & 2 & $86(43)$ & 0.006 & 1.26 & 01464515 & $\begin{array}{l}70 \text { EPA HAL } \\
50 \text { NY MCL }\end{array}$ & $8 \mathrm{CAN}$ & 0 \\
\hline Metribuzin & Lexon, Sencor & 0.004 & 19 & $4(2)$ & 0.028 & 0.049 & 01464515 & $\begin{array}{r}100 \text { EPA HAL } \\
50 \text { NY MCL }\end{array}$ & $1 \mathrm{CAN}$ & 0 \\
\hline Napropamide & Devrinol & 0.003 & 21 & $2(1)$ & 0.009 & 0.009 & 01411790 & $50 \mathrm{NY}$ MCL & -- & -- \\
\hline Pebulate & Tillam, PEBC & 0.004 & 21 & $2(1)$ & E0.003 & E0.003 & 01399780 & -- & -- & -- \\
\hline Pendimethalin & Prowl, Stomp, Pre-M & 0.004 & 21 & $2(1)$ & E0.003 & E0.003 & 01379000 & 50 NY MCL & -- & -- \\
\hline Prometon & Pramitol, Princep & 0.018 & 3 & $84(42)$ & E0.011 & 0.059 & 01411790 & $\begin{array}{c}100 \text { EPA HAL } \\
50 \text { NY MCL } \\
\end{array}$ & -- & 0 \\
\hline Simazine & $\begin{array}{l}\text { Princep, Caliber 91, } \\
\text { Gesatop }\end{array}$ & 0.005 & 4 & $78(39)$ & 0.008 & 0.524 & 01379000 & 4 EPA MCL & $\begin{array}{r}10 \mathrm{CAN} \\
0.5 \mathrm{NY}\end{array}$ & 0 \\
\hline Tebuthiuron & Spike, Tebusan & 0.010 & 12 & $16(8)$ & E0.005 & 0.161 & 01309100 & $\begin{array}{c}500 \text { EPA HAL } \\
50 \text { NY MCL }\end{array}$ & 1.6 CAN & 0 \\
\hline Terbacil & Sinbar & 0.007 & 15 & $10(5)$ & E0.019 & E0.061 & 01475000 & $\begin{array}{l}90 \text { EPA HAL } \\
50 \text { NY MCL }\end{array}$ & -- & 0 \\
\hline Trifluralin & $\begin{array}{l}\text { Treflan, Tri-4, Trific, } \\
\text { Gowan }\end{array}$ & 0.002 & 12 & $16(8)$ & E0.002 & E0.003 & 01394500 & $\begin{array}{c}5 \text { EPA HAL } \\
50 \mathrm{NY} \text { MCL }\end{array}$ & $0.1 \mathrm{CAN}$ & 0 \\
\hline
\end{tabular}

with USEPA MCL's and other water-quality criteria. Data containing an "E" prefix were included in the data set of detected values used for statistical analysis. Data containing a "<" prefix were not included in the computation of median values. The 22 pesticides not detected in any of the samples are listed in table 3 . The relations of pesticide concentrations and detection frequencies to land use are summarized in table 4.

Water-quality criteria have been established for 22 of the 25 compounds detected. The USEPA has established MCL's for drinking water or HAL's for lifetime exposure for 15 of the 25 compounds detected. No concentration of an individual pesticide detected during this study exceeded the USEPA MCL or HAL.

USEPA MCL's are equal to those established by the States of New Jersey and New York. New York State has established MCL's of $50 \mu \mathrm{g} / \mathrm{L}$ for 17 of the 25 compounds detected and an MCL of $5.0 \mu \mathrm{g} / \mathrm{L}$ for dieldrin.

Water-quality criteria for aquatic life have been established for 15 of the detected compounds by the USEPA, New Jersey Department of Environmental Protection, New York State Health Department, Canadian Council of Resource and Environment Ministers, or International Joint Commission of Canada and United States. Only dieldrin and methyl-azinphos were detected in a concentration that equaled or exceeded any of these water-quality criteria (table 2). The New York State criterion for dieldrin $\left(6.0 \times 10^{-7} \mu \mathrm{g} / \mathrm{L}\right)$ was exceeded at three sites on Long Island (sites 6, 8, and 9; see fig. 1). The measured concentration of methyl-azinphos at Mantua Creek at Pitman, N.J. (01475000), was estimated at $0.0101 \mu \mathrm{g} / \mathrm{L}$, which is equivalent to the USEPA freshwater chronic criterion for aquatic life of $0.01 \mu \mathrm{g} / \mathrm{L}$. 
Table 3. Pesticides not detected in 50 stream samples collected in New Jersey and Long Island, New York, June 9-18, 1997

[NWQL, National Water Quality Laboratory; MRL, minimum reporting level; $\mu \mathrm{g} / \mathrm{L}$, micrograms per liter]

\begin{tabular}{|l|l|c|}
\hline Compound name (NWQL) & \multicolumn{1}{|c|}{ Trade name } & $\begin{array}{c}\text { MRL } \\
(\mu \mathrm{g} / \mathrm{L})\end{array}$ \\
\hline Butylate & Genate Plus, Suntan+ & 0.002 \\
\hline DDE,p,p- & Metabolite of DDT & 0.006 \\
\hline Diethlanaline & Metabolite of alachlor & 0.003 \\
\hline Disulfoton & Disyston, Frumin AL & 0.017 \\
\hline EPTC & Eptam, Farmarox & 0.002 \\
\hline Ethal uralin & Sonalan, Curbit & 0.004 \\
\hline Ethoprop & Mocap, ethoprophos & 0.003 \\
\hline Fonofos & Dyfonate, Capfos & 0.008 \\
\hline HCH,alpha- & alpha-BHC, alpha-lindane & 0.002 \\
\hline HCH,gamma- & Lindane, gamma-BHC & 0.004 \\
\hline Molinate & Ordram & 0.004 \\
\hline Parathion, Ethyl- & Roethyl-P, Alkron & 0.004 \\
\hline Parathion, Methyl & Penncap-M & 0.006 \\
\hline Permethrin, cis- & Ambush, Astro & 0.005 \\
\hline Phorate & Thimet, Granutox & 0.002 \\
\hline Pronamide & Kerb, Propyzamid & 0.003 \\
\hline Propachlor & Ramrod, Satecid & 0.007 \\
\hline Propanil & Stampede, Stam & 0.004 \\
\hline Propargite & Omite, Alkyl sul te & 0.013 \\
\hline Terbufos & Counter, Contraven & 0.013 \\
\hline Thiobencarb & Bolero, Saturn & 0.002 \\
\hline Triallate & Avadex BW, Far-Go & 0.001 \\
\hline & & \\
\hline
\end{tabular}

\section{Detection Frequency}

Pesticides were detected at all sites in the study area.

Detection frequencies were computed by using (1) all pesticideconcentration data and (2) only those concentrations exceeding a common threshold of $0.01 \mu \mathrm{g} / \mathrm{L}$ to determine whether the use of different laboratory MRL's for different compounds would affect the results. The seven most frequently detected compounds (figs. 2 and 3) were the same regardless of the method used, but prometon was the most frequently detected compound and carbaryl was detected more frequently than simazine and desethyl-atrazine when $0.01 \mu \mathrm{g} / \mathrm{L}$ was used as a common threshold. All subsequent discussion of detection frequencies in this report refers to those computed by using all data received from the NWQL.

The 25 pesticide compounds detected in the 50 stream samples collected for this study consist of 17 herbicides, 7 insecticides, and 1 degradation product (fig. 2). The seven most frequently detected compounds were atrazine (in 94 percent of samples), metolachlor (86 percent), prometon (84 percent), desethyl-atrazine (78 percent), simazine (78 percent), carbaryl (44 percent), and diazinon (44 percent). Four of the seven most frequently detected compounds are herbicides, two are insecticides, and one is a degradation product of atrazine. In another recent study of water in a network of 72 monitoring wells in southern New Jersey, six of these seven pesticides were among the most frequently detected in shallow ground water (Stackelberg and others, 1997). The 10 most frequently detected pesticides during the current study also were the 10 most frequently detected in samples from a network of seven sites sampled routinely from April 1996 to April 1997 (Reed and others, 1997; 1998).

Pesticide detection frequencies were examined with respect to predominant land uses associated with the drainage basins of the 50 stream sites. According to the land-use criteria described previously, 18 of the sites are in urban basins, 14 are in forested basins, 10 are in agricultural basins, and 8 are in basins with mixed land use. One of these eight sites meets the criteria for both a forested and an agricultural site and, therefore, was included in the mixed-land-use category.

Detection frequencies were highest in basins with greater than 25 percent agricultural land use. Fourteen of the 25 compounds detected were found most frequently at agricultural sites. Acetochlor, azinphos-methyl, carbofuran, and pebulate were detected only at agricultural sites. All four of these compounds are used only for agricultural purposes in the study area (table 1). Atrazine, metolachlor, and desethyl-atrazine were detected at all agricultural and all mixed-land-use sites. The other pesticides detected most frequently at the agricultural sites are DCPA, alachlor, cyanazine, malathion, carbofuran, terbacil, and linuron. Metribuzin was found at one agricultural and one mixed-land-use site. Atrazine was detected at all but three sites, all of which are in the Coastal Plain and drain basins that contain less than 5 percent agricultural land. Metolachlor was detected at all but seven sites, all of which drain basins that contain less than 3 percent agricultural land; six of the sites are classified as urban and one is forested.

Seven pesticides were detected most frequently at urban sites, and four of these-trifluralin, dieldrin, napropamide, and benfluralin-were detected only at urban sites. Trifluralin is used primarily for lawn care, but also is used in agriculture (table 1).

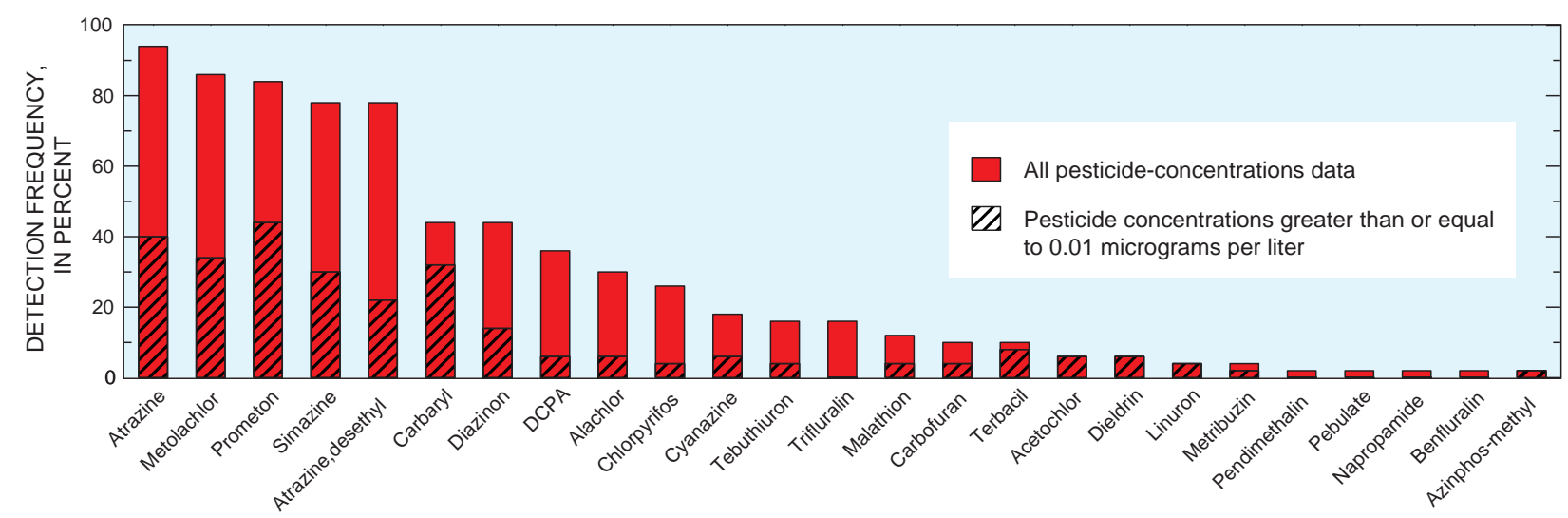

Figure 2. Detection frequencies of pesticides detected in 50 stream samples collected in New Jersey and Long Island, New York, June 9-18, 1997. 
Table 4. Summary statistics for the most frequently detected pesticides in 50 stream samples collected in New Jersey and Long Island, New York, June 9-18, 1997 [The pesticides listed were detected in at least three samples in at least one land-use category and are listed in order of overall detection frequency. Quartiles of detected concentrations were computed for compounds detected in at least three samples per group. NC, not computed; $\mu \mathrm{g} / \mathrm{L}$, micrograms per liter; Red, highest maximum and median concentration and detection frequency for each compound by land-use category]

\begin{tabular}{|c|c|c|c|c|c|c|c|c|c|c|c|c|c|c|c|c|c|c|c|c|}
\hline \multirow{3}{*}{ Compound } & \multicolumn{5}{|c|}{ Agricultural sites $(\mathrm{N}=10)$} & \multicolumn{5}{|c|}{ Urban sites $(\mathrm{N}=18)$} & \multicolumn{5}{|c|}{ Forested sites $(\mathrm{N}=14)$} & \multicolumn{5}{|c|}{ Mixed-land-use sites $(\mathrm{N}=8)$} \\
\hline & \multirow{2}{*}{\begin{tabular}{|c|} 
Detection \\
freq- \\
uency \\
(percent)
\end{tabular}} & \multicolumn{4}{|c|}{ Concentration $(\mu \mathrm{g} / \mathrm{L})$} & \multirow{2}{*}{\begin{tabular}{|c|} 
Detection \\
freq- \\
uency \\
(percent)
\end{tabular}} & \multicolumn{4}{|c|}{ Concentration $(\mu \mathrm{g} / \mathrm{L})$} & \multirow{2}{*}{$\begin{array}{c}\text { Detection } \\
\text { freq- } \\
\text { uency } \\
\text { (percent) }\end{array}$} & \multicolumn{4}{|c|}{ Concentration $(\mu \mathrm{g} / \mathrm{L})$} & \multirow{2}{*}{$\begin{array}{c}\text { Detection } \\
\text { freq- } \\
\text { uency } \\
\text { (percent) }\end{array}$} & \multicolumn{4}{|c|}{ Concentration $(\mu \mathrm{g} / \mathrm{L})$} \\
\hline & & $\begin{array}{c}25 \text { th } \\
\text { percentile }\end{array}$ & Median & $\begin{array}{c}75 \text { th } \\
\text { percentile }\end{array}$ & $\begin{array}{c}\text { Maxi- } \\
\text { mum }\end{array}$ & & \begin{tabular}{c|}
25 th \\
percentile
\end{tabular} & Median & $\begin{array}{c}75 \text { th } \\
\text { percentile }\end{array}$ & $\begin{array}{l}\text { Maxi- } \\
\text { mum }\end{array}$ & & $\begin{array}{c}25 \text { th } \\
\text { percentile }\end{array}$ & Median & $\begin{array}{c}75 \text { th } \\
\text { percentile }\end{array}$ & $\begin{array}{l}\text { Maxi- } \\
\text { mum }\end{array}$ & & \begin{tabular}{|c|}
25 th \\
percentile
\end{tabular} & Median & \begin{tabular}{|c|}
75 th \\
percentile
\end{tabular} & $\begin{array}{c}\text { Maxi- } \\
\text { mum }\end{array}$ \\
\hline Atrazine & 100 & 0.018 & 0.03 & 0.550 & 1.440 & 89 & 0.005 & 0.005 & 0.009 & 0.025 & 93 & 0.004 & 0.005 & 0.008 & 0.051 & 100 & 0.007 & 0.014 & 0.026 & 0.038 \\
\hline Metolachlor & 100 & 0.017 & 0.071 & 0.170 & 1.260 & 67 & 0.003 & 0.003 & 0.009 & 0.075 & 93 & 0.003 & 0.004 & 0.008 & 0.011 & 100 & 0.005 & 0.008 & 0.017 & 0.027 \\
\hline Prometon & 80 & 0.010 & 0.013 & 0.020 & 0.030 & 89 & 0.01 & 0.013 & 0.022 & 0.059 & 79 & 0.006 & 0.006 & 0.008 & 0.021 & 88 & 0.005 & 0.010 & 0.026 & 0,028 \\
\hline Simazine & 80 & 0.005 & 0.010 & 0.047 & 0.51 & 89 & 0.006 & 0.008 & 0.028 & 0.059 & 50 & 0.003 & 0.004 & 0.007 & 0.018 & 100 & 0.002 & 0.010 & 0.106 & 0.524 \\
\hline $\begin{array}{l}\text { Atrazine, des- } \\
\text { ethyl }\end{array}$ & 100 & 0.005 & 0.018 & 0.047 & 0.067 & 56 & 0.002 & 0.002 & 0.003 & 0.005 & 79 & 0.001 & 0.002 & 0.026 & 0.035 & 100 & 0.002 & 0.003 & 0.007 & 0.014 \\
\hline Carbaryl & 50 & 0.005 & 0.015 & 0.047 & 0.09 & 56 & 0.015 & 0.039 & 0.097 & 0.189 & 14 & $\overline{\mathrm{NC}}$ & $\overline{\mathrm{N}}$ & $\overline{\mathrm{NC}}$ & 0.006 & 62 & 0.015 & $\overline{0.041}$ & $\overline{0.064}$ & 0.075 \\
\hline Diazinon & 40 & 0.004 & 0.006 & 0.020 & 0.035 & 61 & 0.005 & 0.008 & 0.013 & 0.074 & 21 & 0.003 & 0.004 & 0.006 & 0.006 & 50 & 0.004 & 0.008 & 0.011 & 0.014 \\
\hline$\overline{\mathrm{DCPA}}$ & 60 & 0.001 & 0.002 & 0.058 & 0.133 & 39 & 0.001 & 0.001 & 0.004 & 0.287 & 21 & 0.001 & 0.002 & 0.006 & 0.006 & 25 & $\mathrm{NC}$ & NC & $\mathrm{NC}$ & 0.002 \\
\hline Alachlor & 70 & 0.005 & 0.006 & 0.020 & 0.089 & 6 & $\mathrm{NC}$ & $\mathrm{NC}$ & $\mathrm{NC}$ & 0.002 & 29 & 0.002 & 0.003 & 0.004 & 0.005 & 38 & 0.002 & 0.005 & 0.006 & 0.006 \\
\hline $\begin{array}{l}\text { Chlorpyrifos } \\
\end{array}$ & 10 & $\mathrm{NC}$ & $\mathrm{NC}$ & $\mathrm{NC}$ & 0.005 & 50 & 0.004 & 0.005 & 0.006 & 0.022 & 14 & $\mathrm{NC}$ & $\mathrm{NC}$ & $\mathrm{NC}$ & 0.007 & 12 & $\mathrm{NC}$ & $\mathrm{NC}$ & $\mathrm{NC}$ & 0.005 \\
\hline Cyanazine & 60 & 0.006 & 0.182 & 0.422 & 0.622 & 6 & $\mathrm{NC}$ & $\mathrm{NC}$ & $\mathrm{NC}$ & 0.005 & 0 & $\mathrm{NC}$ & $\mathrm{NC}$ & $\mathrm{NC}$ & $\mathrm{NC}$ & 25 & $\mathrm{NC}$ & $\mathrm{NC}$ & $\mathrm{NC}$ & 0.005 \\
\hline Carbofuran & 50 & 0.006 & 0.007 & 0.012 & 0.132 & 0 & $\mathrm{NC}$ & $\overline{\mathrm{NC}}$ & $\mathrm{NC}$ & $\mathrm{NC}$ & 0 & $\mathrm{NC}$ & $\overline{\mathrm{NC}}$ & $\overline{\mathrm{NC}}$ & $\mathrm{NC}$ & 0 & $\mathrm{NC}$ & $\mathrm{NC}$ & $\mathrm{NC}$ & $\mathrm{NC}$ \\
\hline $\begin{array}{l}\text { Tebuthiuron } \\
\end{array}$ & 10 & $\mathrm{NC}$ & $\mathrm{NC}$ & $\mathrm{NC}$ & 0.003 & 11 & $\mathrm{NC}$ & $\overline{\mathrm{NC}}$ & $\mathrm{NC}$ & 0.083 & 21 & 0.002 & 0.003 & $\overline{0.04}$ & 0.040 & 25 & $\mathrm{NC}$ & $\mathrm{NC}$ & $\mathrm{NC}$ & 0.007 \\
\hline Trifluralin & 0 & $\mathrm{NC}$ & $\mathrm{NC}$ & $\mathrm{NC}$ & $\overline{\mathrm{NC}}$ & 44 & 0.002 & 0.002 & 0.003 & 0.003 & 0 & $\mathrm{NC}$ & $\mathrm{NC}$ & $\mathrm{NC}$ & $\mathrm{NC}$ & 0 & $\mathrm{NC}$ & $\mathrm{NC}$ & $\mathrm{NC}$ & $\mathrm{NC}$ \\
\hline Malathion & 30 & 0.005 & 0.005 & 0.008 & 0.008 & 11 & $\mathrm{NC}$ & $\mathrm{NC}$ & $\mathrm{NC}$ & 0.012 & 7 & $\mathrm{NC}$ & $\mathrm{NC}$ & $\mathrm{NC}$ & 0.011 & 0 & $\mathrm{NC}$ & $\mathrm{NC}$ & $\mathrm{NC}$ & $\mathrm{NC}$ \\
\hline Acetochlor & 30 & 0.079 & 0.149 & 0.253 & 0.253 & 0 & $\mathrm{NC}$ & $\mathrm{NC}$ & $\mathrm{NC}$ & $\mathrm{NC}$ & 0 & $\mathrm{NC}$ & $\mathrm{NC}$ & $\mathrm{NC}$ & $\mathrm{NC}$ & 0 & $\mathrm{NC}$ & $\mathrm{NC}$ & $\mathrm{NC}$ & $\mathrm{NC}$ \\
\hline Dieldrin & 0 & $\mathrm{NC}$ & $\mathrm{NC}$ & $\mathrm{NC}$ & $\mathrm{NC}$ & 17 & 0.014 & 0.014 & 0.019 & 0.019 & 0 & $\mathrm{NC}$ & $\mathrm{NC}$ & $\mathrm{NC}$ & $\mathrm{NC}$ & 0 & $\mathrm{NC}$ & $\mathrm{NC}$ & $\mathrm{NC}$ & $\mathrm{NC}$ \\
\hline
\end{tabular}

Dieldrin, which was banned in 1984, was detected only at three sites on Long Island, all of which drain basins with greater than 80 percent urban land. Napropamide is used almost exclusively for agriculture, whereras benfluralin is used for lawn care and golf-course maintenance (table 1). Prometon, diazinon, and chlorpyrifos were the other compounds detected most frequently at urban sites.

Seven compounds were detected most frequently at mixed-land-use sites. Atrazine, desethyl-atrazine, metolachlor, and simazine were detected at all mixed-land-use sites.

Pendimethalin was detected at only one site, a mixed-land-use site. Carbaryl and tebuthiuron also were detected most frequently at mixed-land-use sites. No pesticides were detected most frequently at forested sites.

The pesticides detected most frequently were not necessarily the pesticides applied most heavily (in pounds of active ingredient) in New Jersey. Metolachlor, atrazine, and carbaryl are the only pesticides among the seven most frequently detected that are also among the seven most heavily applied pesticides in New Jersey. Prometon and simazine were found in 84 and 78 percent of the samples, respectively, but ranked 20th and 18th in pounds of active ingredient applied. Diazinon, the seventh most frequently detected pesticide in the study, ranked 14th in pounds of active ingredient applied.

Physical and chemical properties and application rates of pesticide compounds affect their detection frequencies in streams. Prometon may be detected more frequently than expected because of its high solubility in water, low soiladsorption coefficient, and long half-life in soil (U.S. Department of Agriculture, 1995). Higher than expected detection frequencies of simazine, despite its low solubility in water and short half-life in soil, can be explained by its low soil-adsorption coefficient. Larson and others (1995) found a larger percentage of simazine than any other compound in streamwater compared to the amount of pesticide applied within a drainage basin in five of the nine basins studied.

Two of the three most heavily applied pesticides in New Jersey were not frequently detected in this study. Pendimethalin, the third most heavily used pesticide, was detected at only one site. Chlorpyrifos, the second most heavily applied pesticide in
New Jersey, was found at only 26 percent of the sites. This finding is consistent with results of a study of relations between pesticide use and riverine flux in the Mississippi River Basin (Larson and others, 1995). In that study, the percentage of pesticide applied in a basin that was found in the streamwater was much smaller for pendimethalin and chlorpyrifos than for triazine and acetanilide herbicides such as atrazine and metolachlor. In a study by Harrison and others (1993), plots of turf were treated with pendimethalin and chlorpyrifos. No residuals of either pesticide were found in samples of runoff draining the study plots. The low detection frequencies of pendimethalin and chlorpyrifos can be explained by their low water solubilities and high soil-adsorption coefficients. Also, most chlorpyrifos is used for termite control around structures and is less likely than other pesticides to be exposed to direct runoff and transported to streams.

\section{Concentration}

Small concentrations of pesticides were found at all sites in the study area. Concentrations of individual pesticides ranged from 0.001 to $1.44 \mu \mathrm{g} / \mathrm{L}$. Nine pesticides_acetochlor, atrazine, carbofuran, carbaryl, cyanazine, DCPA, diazinon, metolachlor, and tebuthiuron-were detected at concentrations greater than $0.1 \mu \mathrm{g} / \mathrm{L}$. Fourteen of the 50 samples contained one or more of these compounds in a concentration greater than $0.1 \mu \mathrm{g} / \mathrm{L}$.

The relation between summary statistics of measured pesticide concentrations and detection frequencies was determined by grouping sites into land-use categories (table 4). Individual concentrations typically were highest at sites in the land-use category with the highest detection frequencies (fig. 3). The exceptions were DCPA and malathion, whose detection frequencies were highest at agricultural sites but whose concentrations were highest at an urban site, and carbaryl, whose detection frequency was highest at mixed-land-use sites, but whose concentration was highest at an urban site. Median concentrations and detection frequencies also were highest in the same group of sites with the exception of tebuthiuron, which was detected most frequently at mixed-land-use sites despite the presence of the two highest concentrations at urban sites (table 4). 


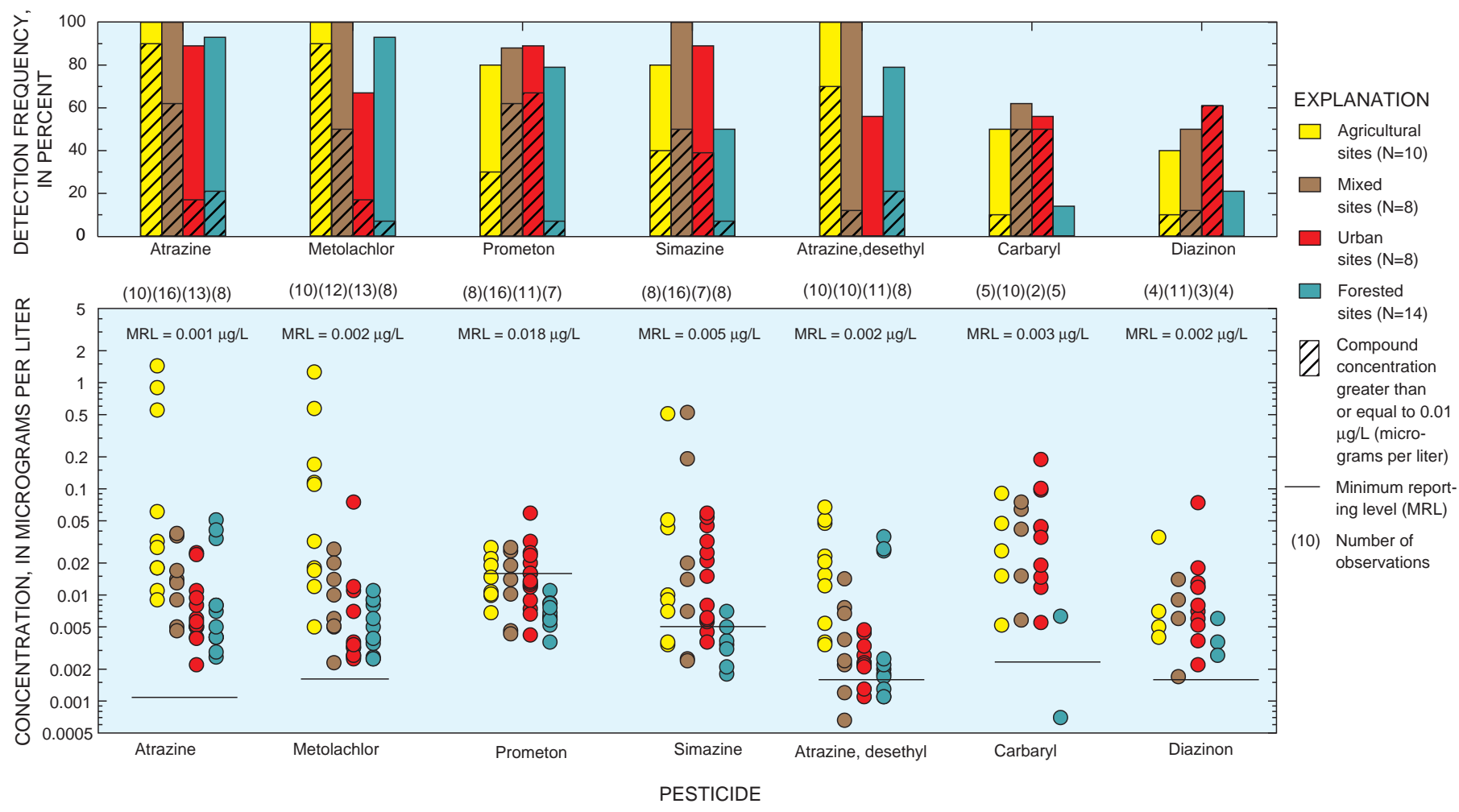

Figure 3. Detection frequencies and concentrations of the most frequently detected pesticides in the 50 stream samples from New Jersey and Long Island, New York, by land-use category.

Pesticide-concentration summary statistics and pesticide detection frequencies for the 50 sites were compared by land-use category (table 4 ). Concentrations of 12 of the 25 pesticides detected were highest at agricultural sites; the concentrations of 11 other pesticides were highest at urban sites. Simazine and pendimethalin were the only compounds whose concentrations were highest at a site with mixed land use.

Atrazine and metolachlor were the only two pesticides detected at concentrations greater than $1.0 \mu \mathrm{g} / \mathrm{L}$. The highest concentration of atrazine $(1.44 \mu \mathrm{g} / \mathrm{L})$ was measured in a sample collected at Stony Brook at Princeton, N.J. (01401000), a site whose basin is 28 percent agricultural land. Metolachlor was detected at $1.26 \mu \mathrm{g} / \mathrm{L}$ in a sample collected at Doctors Creek at Allentown, N.J. (01464515), whose basin is 56 percent agricultural land. In general, atrazine and metolachlor concentrations were highest at sites in basins with the greatest percentage of agricultural land and the smallest percentage of urban land (fig. 4). Median concentrations of atrazine and metolachlor at the 25 sites draining basins with less than 5 percent agricultural land use were 0.005 and $0.003 \mu \mathrm{g} / \mathrm{L}$, respectively. Median concentrations of atrazine and metolachlor at the 25 sites draining basins with greater than 5 percent agricultural land use were 0.02 and $0.01 \mu \mathrm{g} / \mathrm{L}$, respectively. Desethyl-atrazine was the only other frequently detected pesticide whose concentration increased with increasing agricultural land use. No trends were observed between concentrations of other frequently detected pesticides and agricultural land use.

Concentrations of 12 of the 25 pesticides detected were highest at sites in agricultural basins. These pesticides are atrazine, metolachlor, desethyl-atrazine, alachlor, cyanazine, carbofuran, terbacil, acetochlor, linuron, metribuzin, pebulate, and methyl-azinophos. Eight of these compounds are used exclusively in agriculture, one is a degradation product of atrazine, and the remaining three-atrazine, metolachlor, and cyanazine - are used almost exclusively in agriculture (table 1), with only about 0.1 percent used for other purposes. The median concentration of many of these compounds at agricultural sites was significantly greater than the median concentration at sites in drainage basins in other land-use categories-for example, cyanazine (36 times), metolachlor (nine times), desethyl-atrazine (six times), and atrazine (two times). Concentrations of six compounds were highest at Doctors Creek, whose basin is 56 percent agricultural land.

The 11 pesticides found in the highest concentrations at urban sites are prometon, carbaryl, diazinon, DCPA, chlorpyrifos, tebuthiuron, trifluralin, malathion, dieldrin, napropamide, and benfluralin. Concentrations of five of the seven insecticides detected in this study were highest at urban sites. The median concentrations of prometon, carbaryl, diazinon, DCPA, and chlorpyrifos at urban sites, however, were equal to or slightly smaller than the median concentrations of these compounds at sites in other land-use categories. Median concentrations of the other compounds could not be computed and compared to those at sites in other land-use categories because tebuthiuron and malathion were detected at fewer than three sites and trifluralin, dieldrin, napropamide, and benfluralin were detected only at urban sites.

Simazine and pendimethalin were the only compounds whose concentrations were highest at sites in basins with mixed land use. The median concentrations of simazine and diazinon at mixed-land-use sites equal those at agricultural and urban sites, respectively. The median concentration of carbaryl was slightly higher at mixed-land-use sites than at urban sites. 


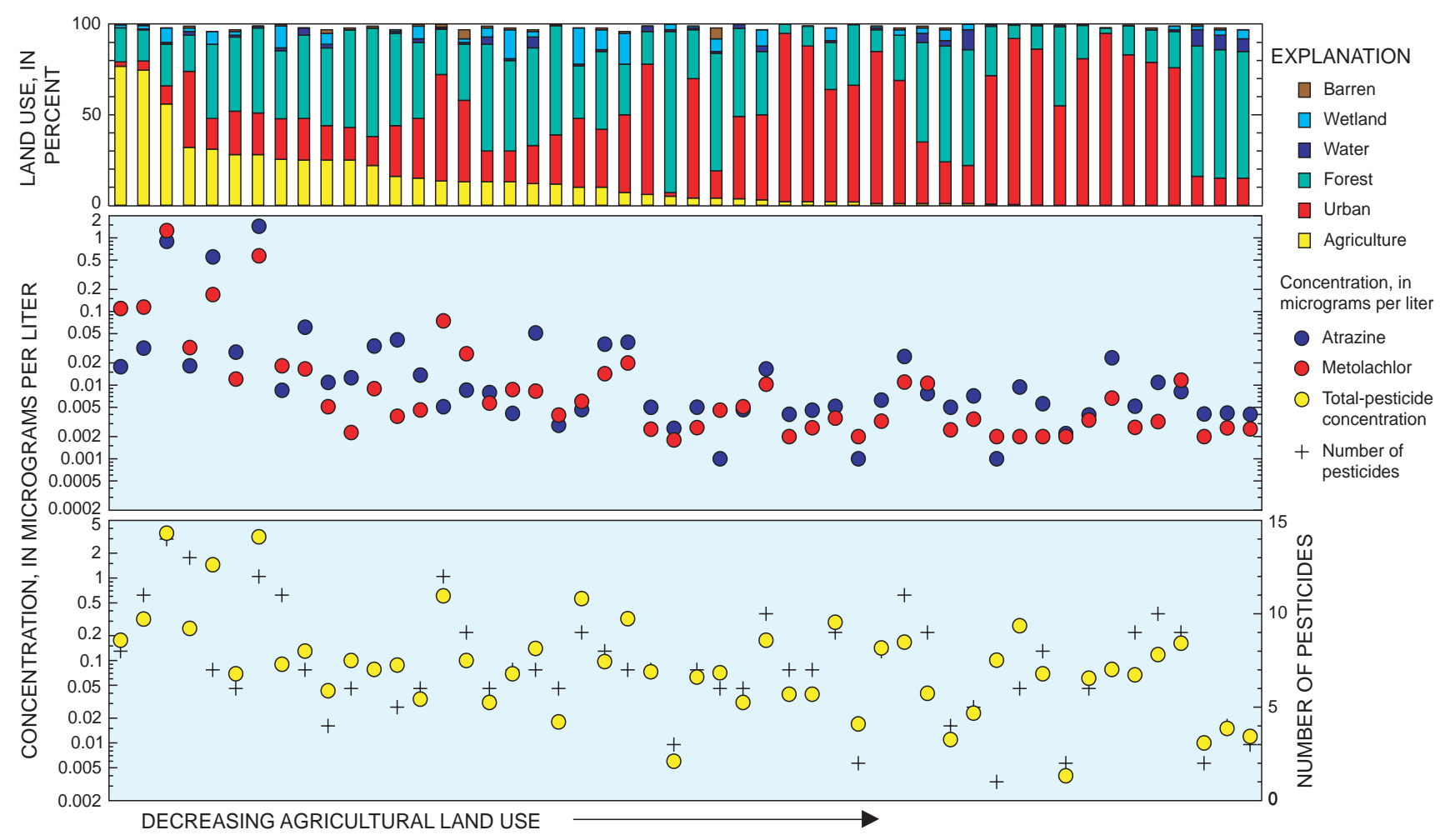

Figure 4. Relation of atrazine and metolachlor concentration, total-pesticide concentration, and number of pesticides detected in 50 stream samples from New Jersey and Long Island, New York, to agricultural land use in associated drainage basins.

\section{Total-Pesticide Concentration and Number of Pesticides Detected}

Total-pesticide concentrations at the 50 sampling sites ranged from 0.0036 to $3.5 \mu \mathrm{g} / \mathrm{L}$. Total-pesticide concentrations generally decreased with decreasing agricultural land use (fig. 4). The median of the total-pesticide concentrations at all sites by land-use category was highest for agricultural sites $(0.2$ $\mu \mathrm{g} / \mathrm{L})$, followed by mixed sites $(0.1 \mu \mathrm{g} / \mathrm{L})$, urban sites $(0.07$ $\mu \mathrm{g} / \mathrm{L})$, and forested sites $(0.026 \mu \mathrm{g} / \mathrm{L})$ (fig. 5). The interquartile range of total-pesticide concentrations was greatest for agricultural sites $(0.09-1.45 \mu \mathrm{g} / \mathrm{L})$ and least for forested sites $(0.012-$ $0.07 \mu \mathrm{g} / \mathrm{L})$. The interquartile range of total-pesticide concentrations at sites draining urban basins was 0.06 to $0.155 \mu \mathrm{g} / \mathrm{L}$ and that at sites draining basins with mixed land use was $0.06 \mu \mathrm{g} / \mathrm{L}$ to $0.20 \mu \mathrm{g} / \mathrm{L}$.

The number of pesticides detected at a site ranged from 1 to 14 (fig. 5). Two or more compounds were present at 49 of the 50 sites sampled; 10 or more pesticides were present at 9 sites. The drainage basins of all nine sites are less than 50 percent forested, those of five of the nine sites are more than 25 percent agricultural, and those of three of the nine sites are more than 50 percent urban. Fourteen pesticides were detected at Doctors Creek at Allentown, N.J. (01464515), a site that drains a basin with 56 percent agricultural land use.

The number of pesticides detected at a site generally increased with the percentage of agricultural land (fig. 4). In general, no relation was observed between number of pesticides and urban land use. As a group, samples from sites whose drainage basins are more than 25 percent agricultural contained more pesticides than samples from sites associated with urban, forested, or mixed land use. The median number of pesticides
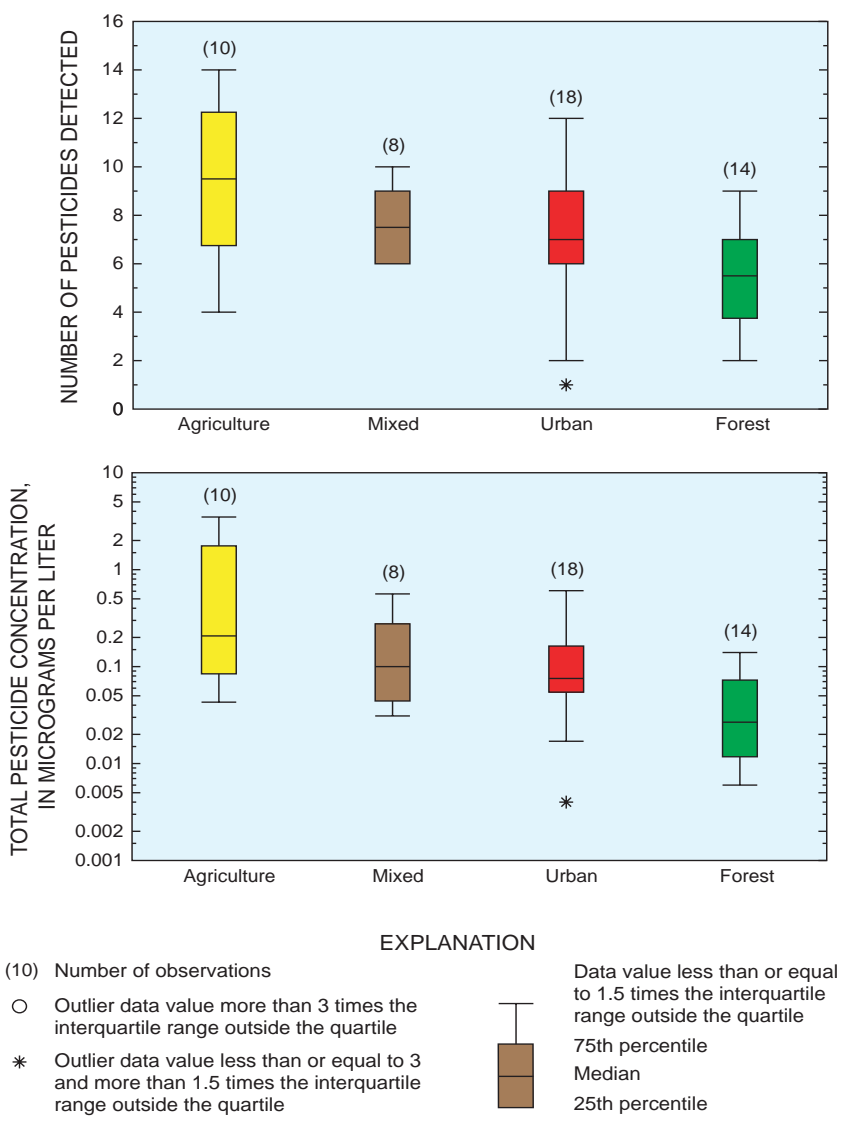

Figure 5. Distribution of number of pesticides detected and total-pesticide concentration in 50 stream samples from New Jersey and Long Island, New York, by land-use category. 


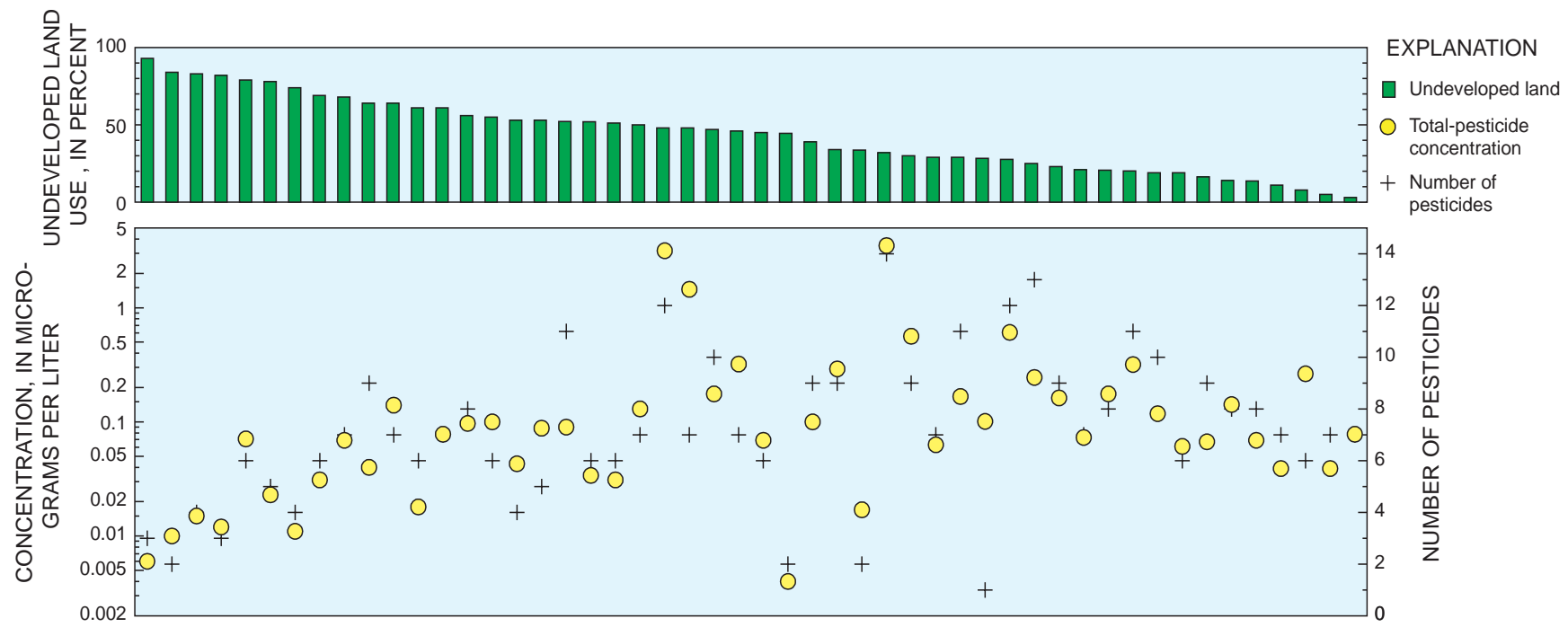

Figure 6. Relation of number of pesticides detected and total-pesticide concentration in 50 stream samples from New Jersey and Long Island, New York, to undeveloped land use in the associated drainage basins.

detected was highest at agricultural sites (9.5) and lowest at forested sites (5.5) (fig. 5).

The number of pesticides detected at a site increased as the percentage of undeveloped land decreased (fig. 6). The high variability in the number of pesticides detected in the middle of the land-use gradient in figure 6 is likely caused by the large mix of land uses. The three low outliers in the middle of the gradient represent sites on three streams on Long Island whose drainage basins contain high percentages of residential and forested land and less than 1 percent agricultural land. The three high outliers in the middle of the gradient represent sites on streams whose drainage basins are more than 25 percent agricultural. The eight basins with the smallest percentage of undeveloped land are highly urban with less than 2 percent agricultural land; the number of compounds detected at the sites in these basins generally was smaller than the number of compounds detected at sites represented by values in the middle of the gradient.

\section{Summary and Conclusions}

Pesticide compounds were detected in all of the 50 stream samples collected during a study of pesticides in surface water in New Jersey and Long Island, New York, conducted June 9-18, 1997. A total of 25 pesticides was detected. The number of pesticides detected at each site ranged from 1 to 14 , with a median of 7 . The seven most frequently detected pesticides were atrazine (in 93 percent of samples), metolachlor (86 percent), prometon ( 84 percent), desethyl-atrazine ( 78 percent), simazine (78 percent), carbaryl (44 percent), and diazinon (44 percent). Only three of these compounds-atrazine, metolachlor, and carbaryl—are among the seven most heavily applied pesticides in New Jersey.

Physical and chemical properties as well as application rates of the pesticides studied affect their detection frequencies. Water solubility and soil-adsorption coefficients appear to be the physical properties that most influence the presence of these compounds in streams. Pendimethalin and chlorpyrifos, two of the three most heavily applied pesticides in New Jersey, have low water solubilities and high soil-adsorption coefficients and, consequently, were found to have low detection frequencies.
Also, because chlorpyrifos is used primarily for termite control, it is less likely than other compounds to be applied in areas exposed to runoff. In contrast, prometon is highly soluble in water and has a low soil-adsorption coefficient; therefore, it had a high detection frequency despite its relatively low application rate.

Detection frequencies of 14 of the 25 pesticides detected were highest at agricultural sites. Four compounds-acetochlor, azinphos-methyl, carbofuran, and pebulate - were detected only at agricultural sites. Seven compounds were detected most frequently at urban sites; four of these-trifluralin, dieldrin, napropamide, and benfluralin — were detected only at urban sites. Four compounds were detected most frequently at mixedland-use sites. No pesticides were detected most frequently at forested sites.

The median concentration and detection frequency of a pesticide always were highest in samples from sites in the same land-use category. The median concentrations of seven pesticides at agricultural sites were at least twice as high as median concentrations at sites in the other land-use categories. The median concentrations of 11 of the 17 herbicides detected were highest at sites in agricultural basins. The median concentrations of the seven compounds detected most frequently at urban sites were equal to or only slightly higher than the median concentrations of these compounds at sites in other land-use categories. Concentrations of five of the seven insecticides detected were highest at urban sites.

The median total-pesticide concentration was highest at agricultural sites $(0.2 \mu \mathrm{g} / \mathrm{L})$ and lowest at forested sites $(0.026$ $\mu \mathrm{g} / \mathrm{L})$. The interquartile range in total-pesticide concentrations was largest at agricultural sites and smallest at forested sites. Total-pesticide concentration and number of pesticides detected at a site increased with increasing agricultural land use and decreased with increasing undeveloped land use in a basin.

MCL's, HAL's, and (or) water-quality criteria have been established for 22 of the 25 compounds detected. No pesticide detected was present in a concentration that exceeded a USEPA, New Jersey, or New York MCL or HAL. Some concentrations of dieldrin and methyl-azinphos, however, equaled or exceeded water-quality criteria for aquatic life. Concentrations of dieldrin 
at three sites on Long Island exceeded the New York State waterquality criterion, and the concentration of methyl-azinphos at one site in New Jersey was equal to the USEPA criterion.

Although all pesticide concentrations were within both USEPA and State MCL's and HAL's, these criteria apply only to individual compounds, and more than one compound was detected in 49 of the 50 samples collected. The long-term cumulative and synergistic effects of multiple compounds on human and aquatic health is an area of active research. The USEPA is considering establishing health standards for combinations of triazine pesticides and for their degradation products (U.S. Environmental Protection Agency, 1994).

- -Robert G. Reiser and Anne K. O’Brien

\section{References Cited}

Buxton, D.E., and Dunne, Paul, 1993, Water-quality data for the Millstone River at Weston, New Jersey, and the Shark River at Remson Mill, New Jersey, March-September 1992: U.S. Geological Survey Open-File Report 93-444, 16 p.

Canadian Council of Resource and Environmental Ministers, 1991, Canadian water quality guidelines: Ottawa, Ontario, Environment Canada, Inland Waters Directorate, Water Quality Branch (updated May 1996), variously paged.

Fegeas, R.G., Claire, R.W., Guptill, S.C., Anderson, K.E., and Hallam, C.A., 1983, Land use and land cover digital data: U.S. Geological Survey Circular 895-E, 21 p.

Ferrari, M.J., Ator, S.W., Blomquist, J.D., and Drysart, J.E., 1997, Pesticides in surface water of the Mid-Atlantic region, 1997: U.S. Geological Survey Water-Resources Investigations Report 97-4280, 12 p.

Harrison, S.A., Watschke, T.L., Mumma, R.O., Jarrett, A.R., and Hamilton, G.W., Jr., 1993, Nutrient and pesticide concentrations in water from chemically treated turfgrass, in Racke, K.D., and Leslie, A.R., eds., Pesticides in urban environments: Fate and significance: American Chemical Society Symposium Series 522, p. 191-207.

Harte, John, and others, 1991, Toxics A to Z: A guide to everyday pollution hazards: Berkeley and Los Angeles, Calif., University of California Press, 479 p.

Hitt, K.J., 1994, Refining 1970's land-use data with 1990 population data to indicate new residential development: U.S. Geological Survey Water-Resources Investigations Report 94-4250, 15 p.

Ivahnenko, Tamara, and Buxton, D.E., 1993, Agricultural pesticides in six drainage basins used for public water supply in New Jersey, 1990: U.S. Geological Survey WaterResources Investigations Report 93-4101, 56 p.

Larson, S.J., Capel, P.D., Goolsby, D.A., Zaugg, S.D., and Sandstrom, M.W., 1995, Relations between pesticide use and riverine flux in the Mississippi River basin: Chemosphere, v. 31, no. 5, p. 3305-3321.

Larson, S.J., Capel, P.D., and Majewski, M.S., 1997, Pesticides in surface waters-Distribution, trends, and governing factors: Chelsea, Mich., Ann Arbor Press, 373 p.

New Jersey Department of Environmental Protection, 1996, New Jersey geographic information system CD-ROM series 1, v. 2.: Trenton, N.J.
New Jersey Department of Environmental Protection, 1998, Surface water quality standards: N.J.A.C. 7:9B: Trenton, N.J., New Jersey Department of Environmental Protection, Office of Environmental Planning, April 1998, 122 p.

New York State, 1998, Water quality regulations for surface and groundwaters: Title 6, Chapter X (Part 703.5, Table 1), 10 NYCRR Subpart 5-1, New York State Health Department Public Water Systems Regulations, effective March 12, 1998.

Reed, T.J., Centinaro, G.L., DeLuca, M.J., Hutchinson, J.T., and Scudder, Jeffrey, 1997, Water resources data for New Jersey-Water year 1996, Volume 1. Surface-water data: U.S. Geological Survey Water-Data Report NJ-96-1, 562 p.

Reed, T.J., Centinaro, G.L., DeLuca, M.J., and Oden, J.H., 1998, Water resources data for New Jersey-Water year 1997, Volume 1. Surface-water data: U.S. Geological Survey Water-Data Report NJ-97-1, 608 p.

Shelton, L.R., 1994, Field guide for collecting and processing stream-water samples for the National Water-Quality Assessment program: U.S. Geological Survey Open-File Report 94-455, 42 p.

Stackelberg, P.E., Hopple, J.A., and Kaufman, L.J., 1997, Occurrence of nitrate, pesticides, and volatile organic compounds in the Kirkwood-Cohansey aquifer system, southern New Jersey: U.S. Geological Survey WaterResources Investigations Report 97-4241, 8 p.

U.S. Bureau of the Census, 1991, Census of population and housing, 1990: Public Law 94-171 data for New Jersey: Washington, D.C., U.S. Bureau of the Census [machinereadable data files (CD-ROM)].

U.S. Department of Agriculture, 1995, ARS Pesticide Properties Database (Last update: May 1995): U.S. Department of Agriculture, Agricultural Research Service (Accessed July 1, 1998, on the world wide web at URL http:// www.arsusda.gov/rsml/ppdb2.html).

U. S. Environmental Protection Agency, 1991, Water-quality criteria summary, Office of Water, Office of Science and Tech., Health and Ecological Effects Division (poster).

1994, Atrazine, simazine, cyanazine: Notice of initiation of special review: Federal Register, v. 59, p. 60412-60443 (Accessed July 8, 1998, on the world wide web at URL http://www.epa.gov/fedrgstr/EPA-PEST/1994/November/ Day-23/pr-54.html).

1995, Guidance for assessing chemical contaminant data for use in fish advisories: Volume 1, Fish sampling and analysis, 2d ed.: Office of Water, EPA 823-R-95-007, 289 p. (plus appendixes). 1996, Drinking water regulations and health advisories, Office of Water, EPA 822-B-96-002, Washington, D.C., October 1996, 16 p.

Ware, G.W., 1994, The pesticide book: Fresno, Calif., Thomson Publications, $386 \mathrm{p}$.

Zaugg, S.D., Sandstrom, M.W., Smith, S.G., and Fehlberg, K.M., 1995, Methods of analysis by the U.S. Geological Survey National Water Quality Laboratory-Determination of pesticides in water by $\mathrm{C}-18$ solid-phase extraction and capillary-column gas chromatography/mass spectrometry with selected-ion monitoring: U.S. Geological Survey Open-File Report 95-181, 49. 


\section{Copies of this report can be purchased from:}

U.S. Geological Survey

Branch of Information Services

Box 25286, Building 810

Denver, CO 80225-0286

Information about the NAWQA Program can be obtained from:

NAWQA Project Chief

U.S. Geological Survey

Mountain View Office Park

810 Bear Tavern Road, Suite 206

West Trenton, NJ 08628

On the web: http://wwwrvares.er.usgs.gov/nawqa/ or http://nj.usgs.gov/nawqa/ 